standing of the common lot among the peoples of his Empire. It needed no more than his simple reminder that as Prince of Wales he had come to know the people of nearly every country of the world and that, though he spoke as the King, he was the same man "whose constant effort it will be to continue to promote the well-being of his fellow-men" to win the most loyal accord of each and every one of his vast audience in his aspiration, "may we be worthy of the heritage which is ours".

For the purpose of King Edward's broadcast, all the stations of the British Broadcasting Corporation were linked together so that his message, delivered from a studio in Broadcasting House, was radiated to all parts of the Empire at home and overseas. According to the various reports, the reception conditions were very good in all parts of the world, and the location of those listening on this occasion was by no means confined to the British Empire. Although this is the first occasion since his accession on which listeners have been able to hear King Edward, he has appeared before the microphone on many previous occasions as the Prince of Wales. $\mathrm{He}$ was the first member of the Royal Family to broadcast, in October 1922, from the first British transmitting station installed at Marconi House. At that time there were less than 18,000 holders of wireless licences in Great Britain, whereas the number of British listeners to the recent broadcast can be safely placed as of the order of tens of millions.

\section{Flying Boats for Empire Air-Routes}

The first six of the twenty-nine big flying boats for Imperial Airways Ltd. are now nearing completion at Messrs. Short Bros.' works at Rochester. The first should be ready during April, and it is hoped to deliver them at regular intervals, completing the order by the end of 1937. Their estimated cruising speed of more than 150 miles per hour will make practicable the promised seven day schedule from England to Australia, allowing the necessary halts for refuelling, with a reasonable time in hand for contingent delays. These new boats will also run on the Bermuda-New York service, in co-operation with the U.S.A. Pan-American Airways, and it is understood that one will be specially fitted for the longrange direct Atlantic flights. They are to be fitted with four Bristol 'Pegasus' engines each of 900 horsepower, using Hamilton controllable-pitch airscrews. The standard form carries 650 gallons of fuel, which gives a range of 540 miles against a head wind of 40 miles per hour. This is considered to be sufficient for most of the Australian journey; but for longer stretches, such as the 1,200 mile crossing of the Tasman Sea to New Zealand, special fuel loads will be necessary, and a consequent adjustment in pay load made. In construction the boats are high-wing monoplanes of exceptionally clean lines. The engines are buried in the wings, and there are practically no excrescences creating drag or interference except the wing tip floats. The hull contains two decks with accommodation for the crew, twenty-four passengers with sixteen sleeping berths, and the usual freightspace.

\section{Germany's New Zeppelin Airship}

THE one hundred and twenty-ninth Zeppelin designed in Germany, the L.Z. 129, will be making its trial flights shortly, and will be officially 'launched' later this month. It is expected to be put into regular service between Frankfort-on-Main and Rio de Janeiro by the end of March. Later in the summer, Dr. Eckener hopes to make some experimental journeys to Lakehurst, New Jersey, U.S.A., but there is no suggestion of the ship being used at present for the North Atlantic services permanently. It is hoped to reduce the time of the normal run to Rio to three and a half days, twenty. four hours less than the present Graf Zeppelin's time. This is due partly to the higher speed of 80 miles per hour-10 miles per hour faster than at present-and to the extra air endurance of 8,000 miles, which will save the necessity for refuelling at Pernambuco. The ship is powered by four com. pression ignition engines of about 1,100 horse-power each, housed in separate gondolas, hung from the flanks of the hull. Each gondola is a self-contained unit, except for its fuel oil, and is connected to the main body by a ladder hatchway. The $130,000 \mathrm{lb}$. of fuel is contained in a series of tanks in the keel of the main hull, interconnected at will, as required. The gas capacity is 7,070,000 cub. ft., twice that of the Graf Zeppelin, contained in sixteen balloonets, each with an inner and outer gas cell. The outer cells may contain helium if desired, as a safeguard against fire, and special arrangements are made to allow the hydrogen to escape from the inner bags if necessary. The ship carries fifty passengers, a crew of forty and about ten tons of paying freight load.

\section{Commercialism and Industrial Research}

Noт many years ago, the British nation was rudely brought to a realisation of its scientific unpreparedness to meet a major world crisis; a crisis which happened to be of a military nature. The Great War came and its passing left us with a vivid ap. preciation of the national, if not of the international, value of scientific research; so that science became news, and there was ample public support for the view that in peace, as in war, our future must depend to a very great extent on our progress in scientific research. Industry has made wonderful strides by its aid, and we have substantially earned the right to regard ourselves as a progressive nation as well as a nation of reasonably successful shopkeepers. But we would do well to review our position afresh, and to ask ourselves whether indeed all is as well as it seems. Prof. J. F. Thorpe, the retiring president of the Institute of Chemistry, spoke, in his presidential address, delivered on March 2, words of some gravity on this subject.

Prof. Thorpe referred, for example, to the danger to which our home industries and our research organisations are exposed when not only finished materials, but also processes, are purchased abroad. Such purchase, unless proved to be in the public interest, means that so much less chance is afforded our research schools to foster national industry, and 